\title{
上部尿路上皮性腫瘍の臨床的ならびに細胞学的研究
}

\author{
第 2 編 Brushing 法による上部尿路上皮性腫瘍の早期確定診断
}

慶応義熟大学医学部泌尿器科学教室 早 川 正 道
(主任 : 田崎
寛教授 $)$

\section{THE CLINICAL AND CYTOLOGIC STUDIES ON UROTHELIAL TUMORS OF THE UPPER URINARY TRACT}

REPORT 2: Accurate and early diagnosis of upper urothelial tumors using brushing technique

Masamichi Hayakawa

Department of Urology, Keio University School of Medicine

(Director: Prof. H. Takiza)

An accurate early diagnosis of filling defects in the renal pelvis and ureter still remians difficulat in spite of popularized selective angiographic technique which are useful for urinary tract malignancies.

On the other hand, exfoliative urinary cytology is useful as a screening method of whole urinary tracts, however, it has little value in differentiating low grade papillary transitional carcinoma from papilloma or benign urothelial lesions. Another problem is the difficulty to determine where these cells come from especially in case cystoscopy is negative. Ureteral catheterization to collect one side urine may be useful but the technique is unable to eliminate cytological contaminations. The disadvantage is seen in any other preliminary brushing techniques unless they do not have the equipment for prevention of cellular contamination.

Our retrograde brushing technique is to use specially designed brush-tip catheter with a top lid which prevents to loose accommodated specimen and does not pick up specimens from other parts. The specimen containing a large number of cells yields more accurate diagnosis such as grading of malignancy.

Our experience with retrograde brushing technique has obtained a 93 per cent diagnostic accuracy in 15 cases of upper urinayr tract lesions.

\author{
緒言 \\ 上部尿路腫瘍, とくに腎盂尿管腫瘍は, 最近の増加傾 \\ 向にもかかわらず, 早期発見が遅れ，根治の機会を失う \\ 例が少なくない. 一方早期の分化型尿管腫瘍に対して \\ は，尿管部分切除 ${ }^{12}$ を施行することの是非について議 \\ 論があるが，この場合も早期診断の上に，術前における \\ 正確な grading の決定が要求されている. \\ 著者は，第 1 編に和いて腎孟尿管腫瘍の予後を決定す \\ る因子として, 細胞学的悪性度, 浸潤度, ならびに早期 \\ 診断が重要であることを報告した。そこで今回，上部尿 \\ 路上皮性腫瘍の正確な早期診断の目的で, 先端に天蓋
}

(top-lid) をつけた retrograde brushing の方法を考案 し, 臨床面に応用して優れた結果が得られたので報告す る.

\section{研究材料並びに研究方法}

血管造影用 guide wire の先端に天蓋 (top-lid) を付 け，その下方 $1 \mathrm{~cm}$ 以内に nylon brush を装着させた brushing-catheter を考案し（Fig. 1)，これを尿管カテー テル内に収納し, 従来の逆行性尿管カテーテル法によつ て挿入し (Fig. 2)，X線透視下にて目的部位に達した のち, brush の部分をカテーテルから出し, 擦過して細 胞を採取する. 擦過後, 直ちに brush の部分を尿管力 
Fig. 1 Brushing instrument with a mashroom like top-lid protruding from open-end ureteral catheter.

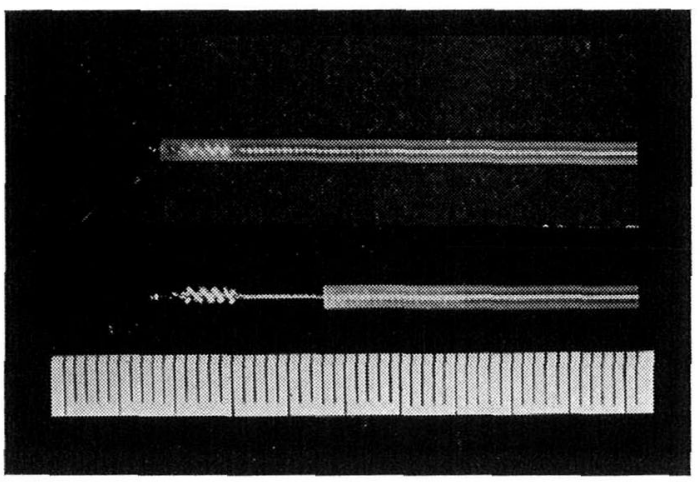

テーテル内に引込み, 天蓋（top-lid）で盍をする. 抜去 後，スライドグラス上に塗布して通常の Papanicoloau
染色を行なら，同時に brush を生理食塩水中で振燙洗浄 し, 艺の洗浄液を, $8 \mu$ の Nucleopore filter membrane にて濾過してフィルター上に細胞を捕捉し，これを染色 して観察した。

\section{研究結果}

1975年から1977年にかけて, 慶応義塾大学病院牤よび 関連病院入院した症例のらち, 尿路X線検查と尿中剝離 細胞診で，上部尿路腫瘍が焱われた15症例について，術 前に逆行性擦過細胞診を行ない，検討を試みた（Table 1). 15症例の病理組織診断の内訳は, 悪性疾患で原発性 腎血尿管腫瘍（移行上皮癌） 7 例，転移性尿管癌 1 例， 良性疾患では腎孟および尿管の良性疾患 7 例であつた。 尿中䟝離細胞診は原則として各症例とも3 回以上施行し て, Papanicolaou 染色倸る class 1,2 and 3 を陰 性, class 4 and 5を陽性として取り扱つた。

Table 1 Comparison of clinical diagnosis, histological diagnosis, exfoliative urinary cytology and retrograde brushing cytology. ( I ) Malignant cases ( II ) Benign cases

( I ) Malignant lesions

\begin{tabular}{c|c|c|l|c|l|c}
\hline Case & Age & Sex & \multicolumn{1}{|c|}{ Clinical dx } & $\begin{array}{l}\text { Urinary } \\
\text { cytology }\end{array}$ & \multicolumn{1}{|c}{ Histology } & $\begin{array}{c}\text { Brushing } \\
\text { cytology }\end{array}$ \\
\hline 1 & 47 & F & Metastatic rectal carcinoma & $1-2$ & $\begin{array}{l}\text { Metastatic carcinoma of } \\
\text { ureter (adenocarcinoma) }\end{array}$ & 4 \\
\hline 2 & 54 & M & Carcinoma of renal pelvis & 5 & $\begin{array}{l}\text { Transitional cell } \\
\text { carcinoma G-3 }\end{array}$ & 5 \\
\hline 3 & 52 & M & Renal tuberculosis & $2-3-5$ & $\begin{array}{l}\text { Transitional cell } \\
\text { carcinoma G-2 }\end{array}$ & 5 \\
\hline 4 & 65 & M & Carcinoma of ureter & $1-3-5$ & $\begin{array}{l}\text { Transitional cell } \\
\text { carcinoma G-4 }\end{array}$ & 5 \\
\hline 5 & 66 & M & Carcinoma of ureter & $1-2$ & $\begin{array}{l}\text { Transitional cell } \\
\text { carcinoma G-2 }\end{array}$ & 4 \\
\hline 6 & 63 & F & Carcinoma of renal pelvis & $3-5$ & $\begin{array}{l}\text { Transitional cell } \\
\text { carcinoma G-2 }\end{array}$ & 4 \\
\hline 7 & 49 & M & Carcinoma of renal pelvis & $3-4$ & $\begin{array}{l}\text { Transitional cell } \\
\text { carcinoma G-2 }\end{array}$ & 3 \\
\hline 8 & 71 & M & Carcinoma of renal pelvis & $2-3$ & $\begin{array}{l}\text { Transitional cell } \\
\text { carcinoma G-3 }\end{array}$ & 5 \\
\hline
\end{tabular}

( II ) Benign lesions

\begin{tabular}{c|c|c|l|c|l|c}
\hline Case & Age & Sex & \multicolumn{1}{|c|}{ Clinical dx } & $\begin{array}{c}\text { Urinary } \\
\text { cytology }\end{array}$ & \multicolumn{1}{|c}{ Histology } & $\begin{array}{c}\text { Brushing } \\
\text { cytology }\end{array}$ \\
\hline 1 & 52 & $\mathrm{~F}$ & $\begin{array}{l}\text { Staghorn calculus \& } \\
\text { Carcinoma of renal pelvis }\end{array}$ & $2-3$ & Inflammatory polyp & 2 \\
\hline 2 & 42 & $\mathrm{M}$ & Carcinoma of ureter & 3 & Ureteral polyp & 1 \\
\hline 3 & 19 & $\mathrm{M}$ & Carcinoma of ureter & $1-3-4$ & Ureteritis & 1 \\
\hline 4 & 32 & $\mathrm{M}$ & Carcinoma of ureter & $1-2$ & Inflammatory polyp & 1 \\
\hline 5 & 65 & $\mathrm{~F}$ & Carcinoma of ureter & $1-2$ & Ureteritis & 2 \\
\hline 6 & 72 & $\mathrm{~F}$ & $\begin{array}{l}\text { Radiolucent renal } \\
\text { Pelvic calculus }\end{array}$ & $2-3-4$ & Renal bleeding & 2 \\
\hline 7 & 63 & $\mathrm{~F}$ & Ureteral stricture & 2 & Inflammatory polyp & 1 \\
\hline
\end{tabular}


Fig. 2 Ureteral brushing catheter in right ureter.

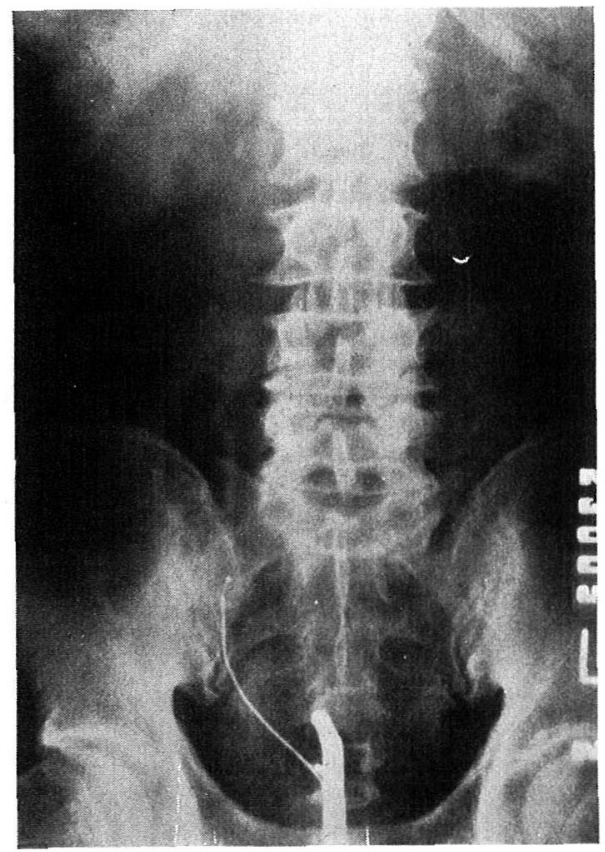

Fig. 4 Retrograde pyelography demonstrating filling defects and stricture of left ureter.

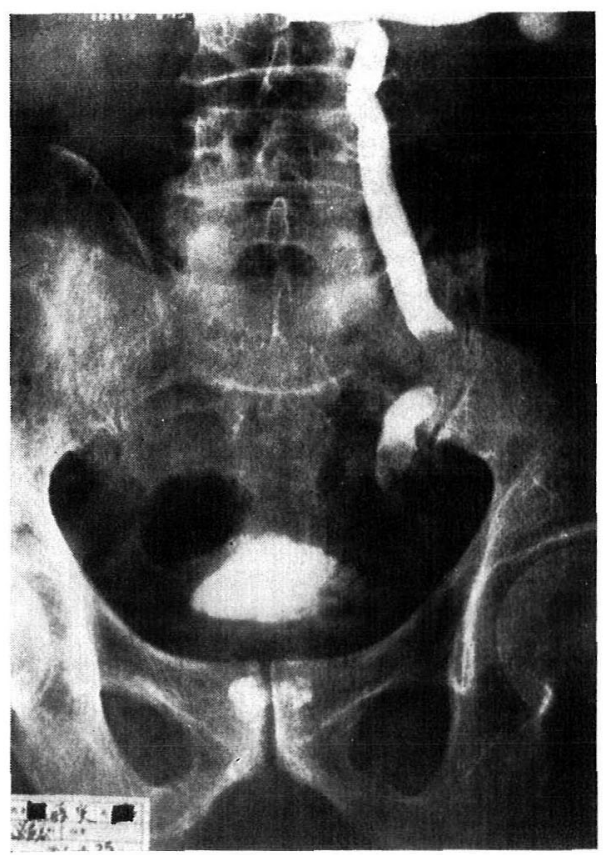

Fig. 3 Displacement of right lowermost ureter by calcified spots.

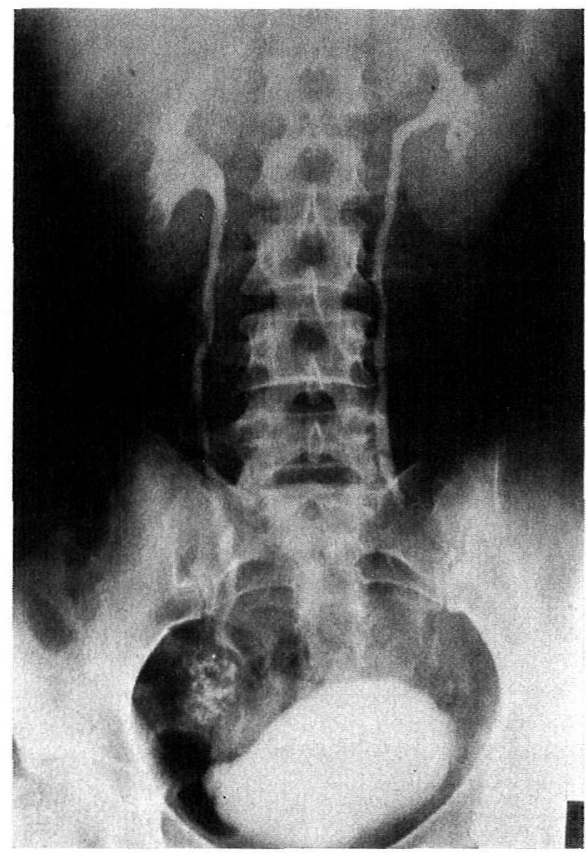

Fig. 5 Retrograde pyelography demonstrating filling defects of left upper ureter.

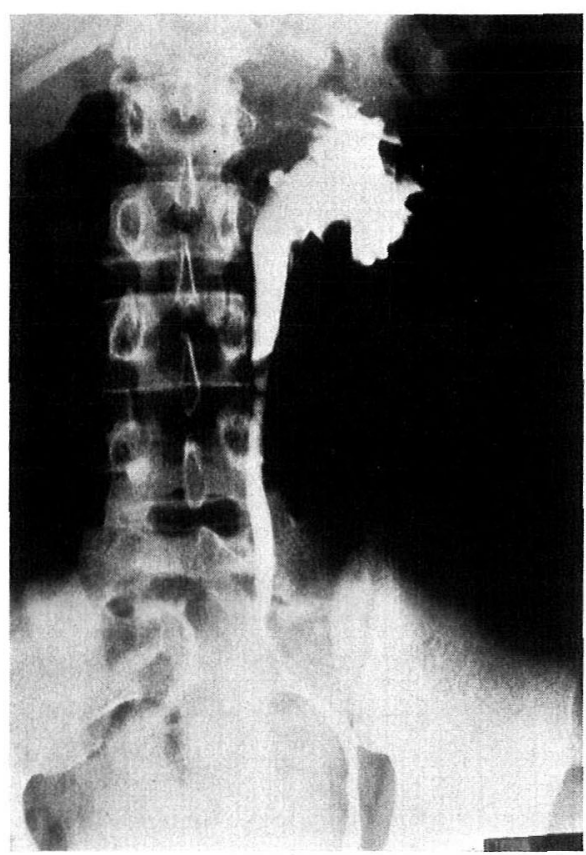


Fig. 6 Malignant cells brushed from renal tumor.

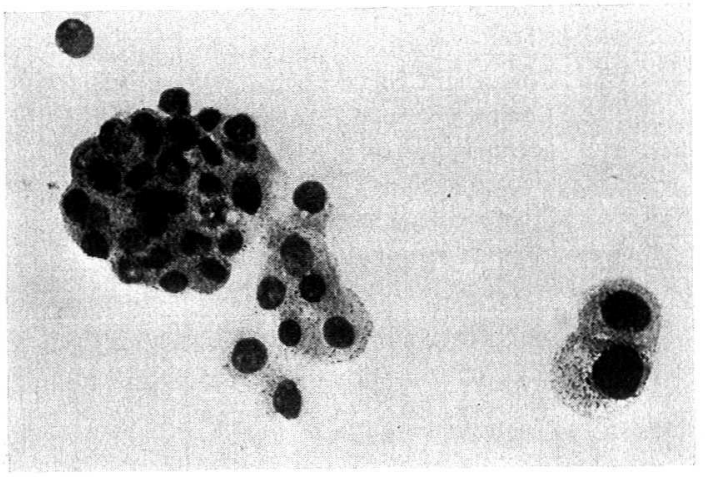

Fig. 8 Cluster of malignant cells brushed from renal tumor.

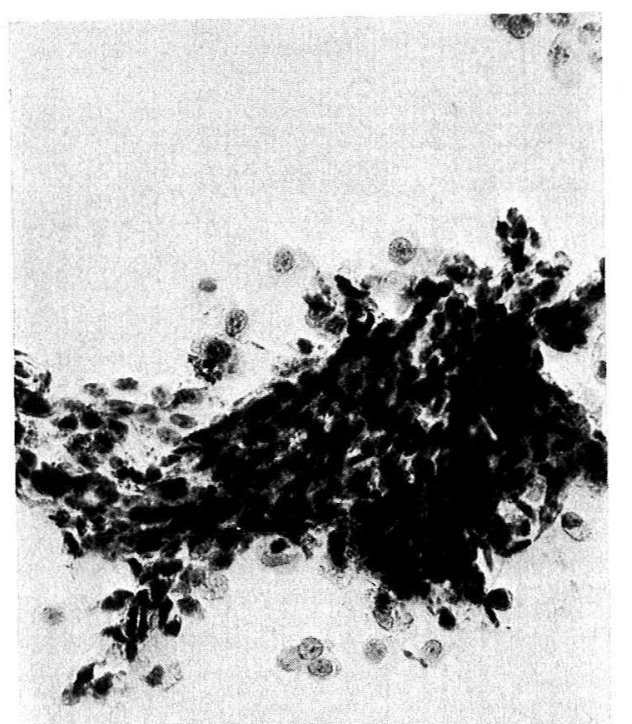

尿中剝離細胞㡎では，悪性疾患 8 症例中つねと false negative を示した例が 3 例あつた。 2 例は, Table 1 の case 1 (Fig. 3) および case 5 (Fig. 4) で, X線検查 上明らかに悪性属瘍が氮われたが，細胞喨でいずれも class 1 , and 2 と, false negative を呈した.さらに良 性疾患 7 症例中, false positive を旺した症例が 2 例認 められた。 らち 1 例は, Table 1 の case 3 で, 血尿を呈 した19歳の男子で, 逆行性腎盂造影にて Fig. 5 のごと くであり,さらに尿細胞䛦で class 4 と䛦断された症例
Fig. 7 Exfoliative malignant cells. (Autosmear technique)

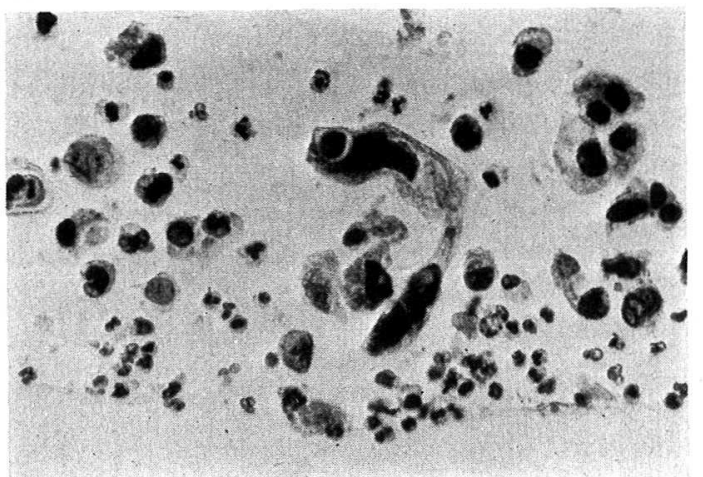

である。

これに対して, 逆行性擦過細胞診では上記の疾患例を 含さ良性疾患中に, false positive がなく, 悪性疾患 8 例中に class 30 false negative が 1 例認められるのみ で，15例中14例に組織診による診断との一致が認めら れ, correct diagnosis は93\%であつた。

15例の症例中に認められたこの検査法の合併症とし て, 尿管損傷および造影剂の尿管外への漏出と, 検側よ りの出血を内視鏡的に確認した 1 例があつたが，尿管カ テーテルを数日間留置して治癒せしめることができた。

\section{考察}

泌尿器科領域に扣ける内視鏡の進步にもかかわらず， 腎杰尿管の検索に内視鏡は一般的でなく，現在のところ X線誩断および尿細胞診に頼らざるをえない現状であ る。尿細胞診は，炎症などの非腫瘍性病変ぬ標本作製手 技により，形態学的な修飾を受け易く，また細胞レベル から組織㡎断を推測することが困難であることにより， いまだ補助的診断法の域を出ないのが実状である．尿路 上皮腫瘍の診断にお汓る尿細胞診の意義については，膀 胱腫瘍を中心に数多く検討されているが，その中で問題 とされる点は, 乳頭腫や分化型の乳頭状癌における尿中 剥離細胞診と病理組織学的診断との差, および非乳頭状

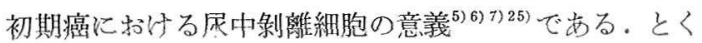
に膀胱乳頭腫においては，剥離する個々の細胞の形態よ り良性と診断する場合がほとんどであるにすかかわら ず，最近の傾向として臨床的には悪性に準ずるとして認

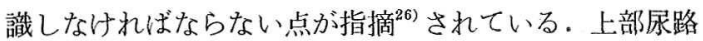
上皮腫瘍の初期癌についての報告 は散見することがで き, この場合の診断にも尿細胞診が重要となつている. 
一般的に，尿細胞診の診断率は最近 の 報告 ${ }^{10)}$ 17) でも， $30 \sim 80 \%$ と広い幅があつて, 当然のことながら悪性度の 高い腫瘍では，それがたと光臨床上診断が困難な初期癌 であつても陽性率が高く，一方では分化度の進んだ比較 的良性な腫瘍や，いわゆる乳頭腫では陽性率が著しく低 下し，臨床上問題を提起することになる。

最近，診断率向上の目的で種々の試みがなされ，尿管 カテーテルによる左右別尿採取や上部尿路洗浄液からの

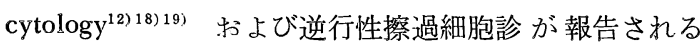
ようになつた。

上部尿路腫瘍の診断に尿中剝離細胞のみならず，さら に積極的に内視鏡を介して腫瘍を生検しようとする試み は，1951年に, Roome and Associates ${ }^{20)}$ により報告さ れている.彼らは Johnson stone basket および cystoscopic biopsy forceps を使用し排泄性又は逆行性腎孟造 影にて上部尿路腫瘍が疑われた 4 例について生検を行な い, 3 例に病理組織診断との一致をみている。次いで Gill ${ }^{12)}$ は, Dormia ureteral catheter $९$ KIFA 型の Angiography catheter を利用し，その内腔を介してナ イロン又はスティール製の粗毛ブラシが付着した針金 を，患部に到達させて擦過し，生検を試みて6 例につき 検討しているが，その中の 1 例として腎杯の一部に浸潤 した腎腺癌を擦過検出できたと報告している。さらに Bibbo $5^{22)}$ と共に 8 例の症例につき検討を加光，同様の 手法にて得られた標本による䛦断を brushing histology としまた擦過後カテーテルを介しての洗浄液による細 胞診を brushing cytology とし，これらを併用すること により100\%の術前診断が可能であると報告している。 気管支や食道の生検用 selector catheter を, 上部尿路 に応用したのが Brown ${ }^{23)}$ で，その catheter 利用の利 点として腎孟内や中・下腎杯への nylon brush の到達 が確実であること，生検と同時に造影剂の注入や患部へ の洗浄も可能であることなどをあげている。本邦では桐 $山^{2425)}$ らが, Dormia stone basket を使用して生検を試 久報告し，多数の細胞塊の採取が可能で，組織診として

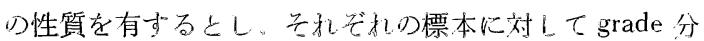
類を行ない，尿細胞診および手術時摘出標本の病理組織 像と比較検討している。

上部尿路上皮腫瘍の生検に際して必要と思われる条件 を Table 2 亿整理したが（第64回日本泌尿器科総会で教 室の田崎が発表したごとく),検査法として容易で，かつ 従来の内視鏡を介しての挿入が可能で，目的部位の細胞 以外の細胞が混入寸ることなく，しか子細胞に十分な量
Table 2 Requirements of brushing cytology for upper urinary tract
1. Absence of contamination
2. Complete collection of specimen
3. Identification of collection site
4. Reproducibility
5. Absence of hemorrage from the lesion
6. Absence of injury to normal area

を途中で他の部位へ落すことなく安全に採取できること が, この擦過用ブラシの優れた点であり，臨床に応用し て極めて良い結果を得ている。

合併症として尿管損傷や尿路感染症があり, Roome ${ }^{20}$ らも逆行性生検に際して尿管穿孔，腫瘍細胞の播種の可 能性や炎症および出血について述べているが，著者らの 蓋付ブラシ（top-lid brush）は，これらの合併症を予防 するためにる有意義であると思われる。

一般的に逆行性擦過細胞診の有用性をまとめると，

(1) 悪性度が高く，尿中剝離細胞診で陽性率の高い腫 瘍に対寸る確定診断にも有効であるが，さらに剥離細胞 の個々の形態の観察では診断が困難とされている low grade の移行上皮癌にも有効な検査法として期待され， 生検としての意義がある.

(2) 自然に㓦離又は脱落し，長期間尿中に浮遊してい る細胞とは異なり，組織の一部としての新鮮な細胞塊を 数多く採取することが可能である.

（3）炎症や非腫瘍性病変の影響を受けにくく，偽陽性 率の低下をるたらす,などである。

これに加えて著者が考案した細胞診用ブラシの特徵と して(1) 部位診断が可能なこと. (2) 腫瘍組織の播種の 危険が少ないこと。があげられる。

また問題点として(1) 採取細胞数が多過ぎる場合重層 し, 従来の透視光線下の細胞診が困難な例があること， (2) brush の長さと尿管への挿入難度が比例する，など があげられる. (1)の例として Table 1の（I）の case 2 亿関して擦過細胞診の Papanicolaou 染色標本 (Fig。 6)を同一患者の auiosmear で処理した尿細胞診（Fig 7) と比較すると, 細胞の集合が顕著で，標本（Fig。8） によつてはさらに重層や集合の傾向が強くなり，従来の Papanicolaou 法の透視光線下の観察では不十分と思わ れる例であつた．本法でとられる細胞塊は立体的なの で, 走查電子顕微鏡による表面構造の観察が有意義と考 えられる。すなわちこの Brushing-Catheter を使い, 得 られた細胞と，手術時摘出標本の表面拈よびそれを直視 
下で擦過して得られた細胞のそれぞれを，走査電子顕微 鏡で観察し，その表面構造・細胞の配列の同一性の面か ら上部尿路に怙ける逆行性擦過細胞診の有用性を確認寸 る必要がある。

\section{結 語}

1）上部尿路腫瘍の早期発見の目的で，標本採取技術 の改良の一環として擦過細胞診用ブラシを考案し，上部 尿路疾患の 15 症例に応用した。

2) 確定診断 (correct diagnosis) は, 悪性腫瘍 8 例 中 7 例 $(88 \%)$ ，良性疾患 7 例中 7 例 $(100 \%)$ で，合計 93\%の correct rate が得られ，擦過細胞診法の有用性 が臨床的に確認された。

\section{文献}

1) Gibson, T.E.: Treatment of transitional cell carcinoma of the upper urnary tract by local resection. Current Controversies in Urologic Management, P. 73 Sanders Co., Philadelphia, 1972.

2) Gibson, T.E.: Local excision in transitioanl cell tumors of the upper urinary tract. J. Urol., 97, 619-622, 1967.

3) Brown, H.E. and Roumani, G.K.: Conservative surgical management of transitional cell carcinoma of the upper urinary tract. J. Urol., 112, $184-187,1974$.

4) 徳中荘平, 厇田紀昭, 辻一郎: 腎孟尿管腫瘍 の臨床と病理。西日泌尿，38，681-685,6, 1976.

5) Melamed, M.R., Voutsa, N.G. and Grabstald, H.: Natural history and clinical behavior of in-situ carcinoma of the human urinary bladder Cancer, 17, 1533-1545, 1964.

6) Melicow, M.M. and Hollowell, J.W.: Intraurotherial cancer: Carcinoma in-situ, Bowen's disease of the urinary systems, discussion of 30 cases. J. Urol., 68, 763-772, 1952.

7) Voutsa, N.G. and Melamed, M.R.: Cytology of in-situ carcinoma of the human urinary bladder. Cancer, 16, 1307-1316, 1963.

8) Murphy, W.M., Buedingen, R.P. and Poley, R.W.: Primary carcinoma in-situ of renal pelvis and ureter. Cancer, 34, 1126-1130, 1974.

9) Allegra, S.R., Fanning, J.P., Streke, J.F. and Corvese, N.M.: Cytologic diagnosis of occult and "in-situ" carcinoma of the urinary system. Acta Cytol., 10, 340-349, 1966.

10) Sarnacki, C.T., McCormack, L.J., Kiser, W.S., Hazard, J.B., McLaughlin, T.C. and Belovich,
D.M.: Urinary cytology and the clinical diagnosis of urinary tract malignancy: A clinicopathologic study of 1400 patints. J. Urol., 106, $761-764,1971$.

11) Eriksson, O. and Johansson. S.: Urothelial neoplasms of the upper urinary tract A correlation between cytologic and histologic finding in 43 patients with urothelial neoplasms of the renal pelvis or ureter. Acta Cytol., 20, $20-25,1976$.

12) Ronald, W.L., Jackson, A.C., Murphy, W.M., Leblance, G.A. and Meehan, L.W.: Cytology in the diagnosis and follow-up of transitional cell carcinoma of the urothelium. J. Urol., 116, 43-46, 1976.

13) Kern, W.H., Bales, C.E. and Webster, W.W.: Cytologic evaluation of transitional cell carcinoma of the bladder. J. Urol., 100, 616-622, 1968.

14) Grace, D.A., Taylor, W.N., Taylor, J.N. and Winter, C.C.: Carcinoma of the renal pelvis: A 15-year review. J. Urol., 98, 566-569, 1968.

15) Sharma, T.C., Melamed, M.R. and Whitmre, W.F.: Carcinoma in situ of the upper urinary tract in patients with bladder carcinoma treated by cystectomy. Cancer, 26, 583-587, 1970.

16) Hawtrey, C.D.: 52 cases of primary ureteral carcinoma: A clinical-pathologic suyd. J. Urol 105, 188-193, 1971.

17) Batata, B. and Grabstald, H.: Upper urinary tract urothelial tumors. Urologic Clinics of North America, 3, 79-86, 1976.

18) Reza, S.M.: Primary tumors of the ureteric stump. Brit. J. Urol., 45, 391-394, 1973.

19) Cummings, K.B., Correa, R.J., Gibbons, R.P., Stoll, H.M. Wheelis, R.F. and Manson, J.T.: Renal pelvic tumors. J. Urol., 113, 158-162, 1975.

20) Roome, N.W., Spooner, C.M. and Filett, R.H. : Biopsy of intra-ureteral tumors by endoscopic means. Brit. J. Urol., 23, 23-28, 1951.

21) Gill, W.B. and Thomsen, S.: Retrograde brushing: A new technique for obtaining histologic and cytlogic material from ureteral, renal pelvis and renal calyceal lesions.J. Urol., 109, 573-578, 1973.

22) Bibbo, M. and Gill, W.B.: Retrograde brushing as a diagnostic procedure of ureteral, renal pelvis and renal calyceal lesions. Acta Cytol., 18, 137-141, 1974.

23) Brown, R.C., Hawtrey, C.E. and Phixley, E. E.: Brush biopsy of the renal pelvis. Amer. J. Roent., 119. 779—782, 1973.

24）林田重昭，桐山帝夫，本憲男，平山 呞： 
尿娳離細胞診 の 臨床的価值. 癌 の臨床, 19 , 482-487, 1973.

25) Kiriyama, T., Hironaka, H. and Fukuda, K.: 6 years of experience with retrograde biopsy of intra-ureteral carcinoma using the Dormai stone basket. J. Utol., 116, 308-310, 1976.

26）山田喬, 三谷玄悟, 横川正之, 稲田俊雄, 大
和田文雄: 膀胱に打ける悪性腯演の䟝離細胞学 的認識。臨床病理, 21, 753-756, 1973 .

27) Sherwood, T.: Upper urinary tract tumors following on bladder carcinoma: Natural history of urothelial neoplastic disease. Brit. J. Radiol. 44, 137-141, 1971.

（1978年 5 月 26日受付，特別掲載） 